\title{
A intercompreensão nas disciplinas de línguas do ensino secundário: um estudo com duas turmas de espanhol em Portugal
}

\author{
Maria Helena Araújo e Sá (D) @ \\ Universidade de Aveiro (UA), Portugal
}

Resumo. A investigação sobre intercompreensão em Didática de Línguas tem vindo a evidenciar os constrangimentos do conceito em termos da sua circulação fora dos espaços académicos, mais concretamente, na escola. Entre outras razões, tais constrangimentos são atribuídos às fragilidades metodológicas da intercompreensão, em especial à ausência de estudos desenvolvidos por professores em contextos educativos concretos, numa perspetiva de inserção curricular. Neste artigo, debruçome sobre um destes contextos específicos e ainda pouco explorados: o ensino/aprendizagem das disciplinas de línguas estrangeiras (aqui, do Espanhol) no ensino secundário (Portugal). Para tal, apresento dois estudos de terreno que coordenei no âmbito do projeto Miriadi, desenvolvidos por dois professores em situação de estágio pedagógico nas suas turmas, com um desenho de investigaçãoação, descrevendo o modo como operacionalizaram o conceito na planificação de unidades didáticas concretas e as potencialidades que Ihe encontraram quanto ao desenvolvimento das competências plurilingues e interculturais dos seus alunos. Os resultados de ambos os projetos permitem afirmar que é possível criar e viver, com autonomia e criatividade, um conjunto didaticamente coerente de situações singulares de ensino/aprendizagem da língua, cujo contributo para o projeto de educação linguística da escola, traduzido, aqui, na disciplina de Espanhol Língua Estrangeira, ficou evidenciado.

Palavras-chave: intercompreensão; currículo; ensino secundário; espanhol língua estrangeira.

La intercomprensión en las asignaturas de lenguas de la educación secundaria: un estudio con dos clases de español en Portugal

Resumen. La investigación sobre la intercomprensión en didáctica de lenguas ha puesto de relieve las limitaciones a la movilidad del concepto fuera de los espacios académicos, más concretamente en la escuela. Entre otras razones, estas limitaciones se deben a las debilidades metodológicas de la intercomprensión, especialmente a la ausencia de estudios desarrollados por docentes en contextos educativos concretos, en una perspectiva de inserción curricular. En este artículo, analizo uno de estos contextos específicos y todavía poco estudiados: la enseñanza/el aprendizaje de las asignaturas de lenguas extranjeras (aquí, del español) en la educación secundaria (en Portugal). Para ello, presento dos estudios de campo que he coordinado en el ámbito del proyecto Miriadi, desarrollados por dos profesores en periodo de prácticas pedagógicas en sus clases, con un diseño de investigación-acción, que describe cómo han hecho operativo el concepto en la planificación de unidades didácticas concretas y el potencial que han encontrado al desarrollar las competencias plurilingües e interculturales de sus estudiantes. Los resultados de ambos proyectos demuestran que es posible crear y vivir, con autonomía y creatividad, un conjunto didácticamente coherente de situaciones únicas de enseñanzalaprendizaje de la lengua, cuya contribución al proyecto de educación lingüística de la escuela, traducido aquí en la disciplina de Español Lengua Extranjera se ha evidenciado.

Palabras clave: intercomprensión; currículum; educación secundaria; español lengua extranjera.

Inter-comprehension in secondary education language courses: a study of two Spanish classes in Portugal

Abstract. Research on inter-comprehension in language teaching has highlighted the limited mobility of this concept beyond academic borders or more specifically, within the school. Among other reasons, these limitations are due to the methodological weaknesses of inter-comprehension, especially due to a lack of research by teachers in specific educational contexts from the perspective of curriculum insertion. This article analyses one of these specific contexts which is yet to be researched in detail: the teaching/learning of foreign language courses (here, Spanish) in secondary education (in Portugal). I present two field studies that I have coordinated within the scope of the Miriadi project, developed by two professors during their teaching internship using a research action design, which describes how they implemented the concept in planning concrete teaching units, and the potential that was discovered upon developing the students' multilingual and intercultural skills. Results of both projects reveal that it is possible to create and live, with autonomy and creativity, a didactically coherent group of situations that are unique to language learning/teaching, whose contribution to language education in schools, integrated here within the discipline of Spanish as a Foreign Language, is demonstrated. Keywords: inter-comprehension; curriculum; secondary education; spanish as a foreign language. 


\section{Introdução}

A intercompreensão (IC) tem vindo a tornar-se um conceito nuclear em Didática de Línguas (DL), em particular no quadro de uma abordagem plurilingue e intercultural da disciplina (Alarcão et al., 2009). Entre os seus indicadores de vitalidade científica, podemos referir a existência de uma comunidade de investigadores consolidada e ativa, organizada em redes internacionais que abrangem vários espaços geográficos, projetos financiados, congressos, publicações, formação contínua e avançada, relatórios, teses e dissertações, referenciais de formação e de avaliação, recursos didáticos, muitos deles de acesso aberto, dirigidos a públicos-alvo diferenciados em termos etários e de níveis de formação (da inicial à contínua, passando pela formação profissional, em contexto de trabalho), entre outros. 0 apoio de agências internacionais de política linguística é inegável e tem contribuído decisivamente para as dinâmicas (e também para os rumos) do conceito. Contudo, é forçoso constatar que pouco se sabe sobre a circulação da IC fora do espaço académico (nas vertentes de formação, investigação e relação com a sociedade), ou, mais concretamente, sobre a sua presença na escola. Dito de outro modo, é notória a falta de conhecimento sobre a forma como a IC é apropriada pelos professores e reconfigurada em práticas de educação linguística concretas, no âmbito de sistemas educativos específicos que apresentam as suas próprias condições de regulação. Com efeito, e com exceção do ensino superior (onde tem vindo a ser realizado o recenseamento das formações, em particular nos espaços europeu e ibero-americano; ver exemplos recentes, como Degache (2018), Miranda de Paulo (2018), Olmo e Rocha (no prelo) e dos primeiros anos de escolaridade (Andrade, Pinho \& Martins, 2011), espaços que podemos considerar, por diferentes razões, de maior autonomia e flexibilidade curricular, são escassos os estudos que se debruçam sobre as práticas de intercompreensão no âmbito da gestão e desenvolvimento curricular das disciplinas escolares, incluindo as de línguas (para uma compilação e análise de alguns destes trabalhos, ver Araújo e Sá \& Pinho, 2015; Araújo e Sá \& Simões, 2015).

Partindo desta constatação, um grupo de trabalho da rede Miriadi ${ }^{1}$ dedicado à inserção curricular da IC, que coordenei entre 2012-2015, construiu um percurso de investigação-ação cuja finalidade era compreender as permeabilidades, oportunidades, desafios, mas também resistências e constrangimentos dos contextos e atores educativos, nas suas múltiplas

${ }^{1}$ MIRIADI - Mutualisation et Innovation pour un Réseau de l'Intercompréhension A distance, foi um projeto europeu que decorreu entre 2012 e 2015, coordenado por Sandra Garbarino (Université de Lyon 2, França). Este artigo vem na sequência de um dos lotes de trabalho deste projeto que coordenei, intitulado: Inserção curricular da Intercompreensão. Para mais informação sobre o projeto e seus produtos, consultar www.miriadi.net. 
regulações, a este conceito reconfigurador de uma abordagem mais humanista, mais implicada, mais holística e plural, em DL (Alarcão \& Araújo e Sá, 2010). Assentando numa perspetiva praxeológica (porque orientada para a intervenção), colaborativa (porque juntou investigadores, formadores, professores e alunos em ações conjuntas) e plurilingue e intercultural (os membros da equipa provinham de vários países e continentes e usavam as suas línguas e variedades de línguas) da DL, este percurso encontra-se detalhadamente relatado em publicações em linha (Araújo e Sá, 2014, 2015; Araújo e Sá \& Pinho, 2015; Araújo e Sá \& Simões, 2015) e dá um panorâmica bastante ampla (em termos de contextos de trabalho, de experiências de inserção curricular, de níveis de educação e formação e de atores envolvidos) da questão em foco. Neste artigo, debruço-me sobre um destes contextos específicos, ainda pouco explorado: a IC no ensino/aprendizagem das disciplinas de línguas estrangeiras (aqui, do Espanhol) no ensino secundário (Portugal), discutindo dois estudos de terreno que coordenei².

\section{Intercompreensão: precisão conceptual}

Conforme mencionado, a IC é uma noção que tem trilhado o seu percurso em DL nos últimos anos. Vários são os grupos que a desenvolvem, em contextos académicos diferenciados (nomeadamente do ponto da tradição epistemológica, das línguas de trabalho e das configurações geográficas das redes de trabalho), o que, se por um lado contribui para as suas dinâmicas científicas, conferindo-Ihe uma espessura conceptual assinalável (para uma síntese, ver estudos incorporados em Ferrão Tavares e Ollivier, 2010), por outro lado, exigem a sua explicitação prévia para fins discursivos.

Num texto recente onde evocam brevemente o percurso da noção, Ollivier, Capucho, e Araújo e Sá (no prelo) referem a sua origem empírica e histórica (relacionada com práticas conversacionais quotidianas de contacto de

2 Estes dois estudos foram realizados no âmbito de estágios pedagógicos supervisionados e deram origem aos seguintes dois Relatórios de Mestrado profissional:

- A integração curricular da intercompreensão numa turma de ELE (Ana Margarida Borges, Mestrado Ensino do Português no 3. ${ }^{\circ}$ CEB e de Espanhol no Ensino Básico e Secundário, 2014). Disponível em http://hdl.handle. net/10773/14302

- Espanhol Língua Estrangeira em intercompreensão - uma proposta de integração curricular (Fernanda Ferreira, Mestrado Ensino do Inglês e de Espanhol no $3 .^{\circ}$ CEB e no Ensino Secundário, 2014). Disponível em http:// hdl.handle.net/10773/14656

Uma síntese de ambos os trabalhos, revista pelas autoras e outros membros da equipa Miriadi, pode ser encontrada em Araújo e Sá (2015). 
línguas ou de variedades de uma mesma língua) e analisam a sua apropriação pela DL, no âmbito das atuais tendências plurilingues e interculturais que marcam a disciplina. Reconhecendo a plasticidade camaleónica do conceito, mas também o seu potencial heurístico e metodológico, desde logo indiciado pelos dois elementos que compõem o termo (o prefixo "inter" - que evoca um processo que se pode referir quer às línguas, quer às culturas, quer aos sujeitos, e o lexema "compreensão" - que cobre a diversidade de situações de comunicação onde tal processo pode ocorrer), os autores apresentam uma perspetiva da IC como um processo de cooperação dialógica que pressupõe "the active involvment of the speakers in the co-construction of meaning, that is, their mutual responsability in the dialogic activity".

Este texto, complementado por outro dos mesmos autores (Capucho, Olliver \& Araújo e Sá, no prelo), interessa-nos aqui particularmente, entre muitos outros que poderiam ser evocados com a mesma finalidade definitória, porque, ao ser elaborado no âmbito do projeto EVAL-IC ${ }^{3}$, tem como objetivo essencial sistematizar as competências de IC identificadas na investigação, como passo prévio para a elaboração de um referencial de avaliação que possa vir complementar outros já disponíveis (em particular o REFIC - Referencial de competências de comunicação plurilingue em intercompreensão, De Carlo, $2015^{4}$ ). Ora a elaboração deste referencial é fundamental para potenciar a presença da IC em contextos educativos fortemente regulados, precisamente porque contribui para uma fragilidade que tem vindo a ser indicada com insistência ao conceito e que trava o seu percurso em ambientes profissionais: o défice metodológico. Com efeito, e conforme escreve Escudé (2010, p. 95): “L'IC n'est pas encore organisé en un corpus définitif aux contours clairs, avec une méthodologie prête à l'emploi et intégrable". Coste (2010) reforça esta constatação, focando a avaliação como uma das vertentes fundamentais do discurso metodológico:

aussi longtemps qu'une innovation didactique ne peut s'accompagner de modalités d'évaluation qui lui soient compatibles et reconnues comme telles, aussi longtemps qu'elle ne trouve pas un nichage adéquat dans les curriculums, elle court le risque d'une marginalisation durable, quand même elle bénéficierait d'un succès d'estime. (Coste, 2010, pp. 195-196).

${ }^{3}$ EVAL-IC - Evaluation des compétences en intercompréhension: réception et interactions plurilingues foi um projeto europeu que decorreu entre 2016 e 2019, com coordenação de Christian Ollivier (Université de la Réunion, França). Informação em http://evalic.eu/.

${ }^{4}$ Este Referencial, que se apoia nos descritores propostos pelo QECR (Quadro Europeu Comum de Referência para as Línguas) e pelo CARAP (Cadre de Référence pour les Approches Plurielles des Langues et des Cultures), foi construído no âmbito do projeto Miriadi. Para uma versão revista, ver De Carlo, M., \& Anquetil, M. (no prelo). Le nouveau REFIC - Un Référentiel de compétences de communication plurilingue en intercompréhension, EL.LE 1/2019. 
Reconhecendo este défice e pretendendo contribuir para o atenuar, Ollivier, Capucho, e Araújo e Sá (no prelo), no quadro de EVAL-IC, analisam as definições operatórias de IC encontradas em 83 estudos publicados, as quais sintetizam as competências de linguagem que ressaltaram de investigações de terreno com corpora. Esta análise integrativa permite-lhes apresentar a seguinte definição:

I'intercompréhension est un mode de communication global qui fait appel à des compétences potentiellement partielles et déséquilibrées dans diverses langues ainsi qu'à des compétences spécifiques additionnelles (métalinguistiques, cognitives, stratégiques, entre autres) et à des dispositions envers la communication, et les associe pour assurer la communication entre individus locuteurs de langues différentes n'ayant pas forcément appris la langue des autres. (Ollivier, Capucho, e Araújo e Sá, no prelo)

É nesta definição alargada mas bastante concisa, decorrente de investigação recente e diversificada na área e que aponta para pistas de exploração didática concreta do conceito, já que identifica componentes da IC que podem ser objeto de trabalho em sala de aula (competências transversais e específicas e disposições), que nos baseamos neste estudo, focalizado sobre uma disciplina de língua estrangeira (LE) no sistema escolar português.

\section{Desenho da investigação-ação}

O estudo assenta em dois projetos de investigação-ação realizados no contexto de dois estágios pedagógicos que orientei e que se inseriram nos princípios e finalidades do grupo de trabalho em inserção curricular da IC de Miriadi (ver notas 1 e 2). Os projetos foram conduzidos pelos professores estagiários ${ }^{5}$, com a supervisão direta, para além do responsável científico da universidade, do professor titular da turma, em duas classes de espanhol língua estrangeira (ELE) com características diferenciadas mas com alunos da mesma faixa etária (10. ${ }^{\circ}$ ano de escolaridade), às quais foi proposto um plano de intervenção didática desenhado de acordo com os princípios didactológicos que a seguir se sistematizam, comuns a ambos os casos.

${ }^{5}$ Importa referir que ambos estes professores estagiários (de Espanhol Língua Estrangeira) já eram profissionalizados noutras disciplinas de línguas e possuíam alguma experiência profissional. 0 facto de estarem a realizar uma nova profissionalização relaciona-se, fundamentalmente, com a vontade de alargar as suas condições de empregabilidade, face às dificuldades de emprego dos professores de línguas em Portugal. 
Com a duração de cerca de três meses, correspondente ao $2 .^{\circ}$ período letivo, os projetos compunham-se de um conjunto de atividades de ensino/aprendizagem específicas para cada turma, estruturadas em torno da sua participação numa sessão de formação na plataforma Galanet intitulada Poliglotta? No, plurilingue!. ${ }^{6}$ Em traços gerais, trata-se de uma formação em ambiente colaborativo, plurilingue e intercultural, com uma duração média de 10-12 semanas, durante a qual grupos de alunos, de diferentes países e línguas (neste caso, românicas), desenvolvem um projeto por eles definido, recorrendo a um conjunto de espaços e funcionalidades (tais como fórum de discussão, chats, salas de reuniões, perfis individuais e de grupo, etc.). As sessões organizam-se em quatro fases ${ }^{7}$ :

- quebrar o gelo e escolha do tema (definição do perfil pessoal e da turma e proposta e seleção de temas de trabalho);

- turbilhão de ideias (a propósito do tema escolhido, definindo tópicos e grupos de trabalho necessariamente plurilingues para os desenvolver);

- recolha de documentos e debate (a fase mais longa e onde o trabalho didático em IC se intensifica em torno dos documentos depositados pelos grupos);

- dossier de imprensa (síntese escrita final do projeto).

O contrato de comunicação é o seguinte: os participantes trabalham e exprimem-se na(s) sua(s) língua(s) materna(s) ou noutra(s) de escolha e procuram compreender as línguas dos outros, evitando adotar uma língua franca. Este contrato pretende promover uma interação em que todas as línguas presentes têm, potencialmente, idêntica possibilidade de serem utilizadas como línguas de comunicação. No caso das nossas duas turmas, os professores solicitaram que a participação fosse, maioritariamente, realizada em espanhol, como forma de intensificar as oportunidades de uso autêntico da língua de aprendizagem.

A sessão em foco decorreu entre fevereiro e abril de 2014, tendo-se registado na plataforma 11 turmas (169 alunos e 16 tutores): quatro de Portugal (49 alunos); quatro de Itália (79 alunos); uma de Espanha (7 alunos) e duas de França (34 alunos) (ver tabela 1).

${ }^{6}$ De referir que esta foi a última formação Galanet. Por razões tecnológicas, esta plataforma já não se encontra ativa, decorrendo atualmente as sessões de formação em IC na plataforma Miriadi (www.miriadi.net).

${ }^{7}$ Para uma apresentação detalhada da plataforma e da formação, ver Andrade, Araújo e Sá, López Alonso, Melo, e Séré (2005). 
Tabela 1. Equipas participantes da sessão

\begin{tabular}{llc}
\hline Equipas & Países & Número de alunos \\
\hline Falcone - Gli Intercomprensivi & Itália & 25 \\
Os fogacinhas & Portugal & 12 \\
Falcone-Furetti & Itália & 21 \\
Soure & Portugal & 9 \\
Osservatori & Itália & 2 \\
Falcone-Arlecchino & Itália & 31 \\
Soure Español & Portugal & 8 \\
Auray- Iycée BFranklin & França & 18 \\
Bellvitge-Hospitalet & Espanha & 7 \\
Boisfleury & França & 16 \\
Tugas à Beira-Ria & Portugal & 20 \\
Total & & 169 \\
\hline
\end{tabular}

Fonte: Sessão Poliglotta? No, plurilingue!

As duas turmas aqui em foco designaram-se como "Tugas à Beira-Ria" (caso 1) e "Soure" (caso 2).

Do ponto de vista metodológico, ambos os projetos adotaram uma perspetiva de investigação-ação, dando-se como finalidade "compreender para intervir" e, simultaneamente, "intervir para compreender" (Alarcão, 2010, p. 70; Blanchet, 2011). Dito de outo modo, pretendia-se identificar, do ponto de vista dos sujeitos implicados (professores e alunos), as possibilidades de uma abordagem didática do ELE inspirada na IC. Concretamente, a questão à qual se procurava dar resposta era a seguinte: de que que forma a integração da IC nas aulas de ELE contribui para o desenvolvimento das finalidades e dos objetivos das disciplinas-alvo? Que potencialidades? Que limites? Que constrangimentos?

Para este efeito, foram recolhidos dados naturalistas, constituídos fundamentalmente por: registos dos professores nos seus diários de bordo; gravações das atividades e transcrição de excertos considerados significativos; artefactos produzidos pelos alunos (como respostas a fichas de trabalhos); impressões da participação na plataforma; respostas a questionários. Estes dados foram analisados recorrendo a dispositivos categoriais construídos com base no REFIC (De Carlo, 2015; ver nota 4), o qual propõe cinco dimensões de análise, as duas primeiras de ordem processual e as três outras de ordem comunicativa, referentes a atividades de linguagem específicas, a saber:

- o sujeito plurilingue e a aprendizagem, dimensão relativa ao repertorio linguístico-cultural do aluno, assim como às suas estratégias metacognitivas relativas à gestão, organização e avaliação da aprendizagem; 
- as línguas e as culturas, englobando os conhecimentos reflexivos sobre elas, numa perspetiva plurilingue e intercultural;

- compreensão escrita;

- compreensão oral e audiovisual;

- interação plurilingue.

Para cada uma das dimensões consideradas, o REFIC identifica, descreve e exemplifica descritores específicos. Contudo, assumindo uma abordagem qualitativa da investigação que procura compreender os fenómenos em estudo na perspetiva dos sujeitos atores sociais (ver acima), nos nossos dois estudos, estes descritores (tomados enquanto categorias e sub-categorias de análise) foram também definidos a partir de um procedimento "emic" (Goetz \& Lecompte, 1984), isto é, com base numa leitura flutuante e interpretativa da informação disponível. Por outras palavras, adotou-se um procedimento metodológico inspirado no paradigma indiciário (Ginzburg, 1989), no qual o investigador identifica, articula e interpreta sinais, pistas, indexando-os depois a um quadro geral de referência (aqui, o REFIC), de modo a construir conhecimento específico relativamente aos factos em análise, considerados sempre de um modo singular e situado. Ambos os estudos assumem pois, enquanto características nucleares do seu quadro epistemológico, um caráter heurístico e exploratório, próprios de uma perspetiva de investigação "contextualizada e contextualizante" em DL que privilegia a compreensão aprofundada dos fenómenos à sua generalização e transferência (Blanchet \& Chardenet, 2011).

Definidas assim as linhas gerais do desenho de ambas as intervenções, apresenta-se detalhadamente, nas seções seguintes, cada uma delas.

\subsection{Caso 1 - A IC numa turma de iniciação de Espanhol, área de Humanidades}

Esta intervenção decorreu com uma turma de ELE de Iniciação, 10. ano (que se designou na plataforma Galanet como "Tugas à Beira-mar"), tendo ocupado um total de cinco aulas (mais trabalho autónomo na plataforma Galanet, fora da aula) de duração variável (três aulas de 90 minutos e duas de 135 minutos) (ver Tabela 2).

Os objetivos educativos enunciados pelo professor que a implementou foram os seguintes:

- desenvolver a abertura à diversidade linguística e cultural e adquirir conhecimentos sobre ela; 
- desenvolver estratégias de acesso ao sentido em enunciados escritos produzidos em línguas românicas (LR);

- tomar consciência da diversidade cultural e linguística em Espanha;

- explorar particularidades linguísticas do espanhol em contraste com outras LR;

- tomar consciência das diferenças linguísticas entre textos produzidos por falantes com diferentes níveis de proficiência em espanhol (nativos e não nativos);

- desenvolver competências de interprodução, isto é, de se exprimir para interlocutores que não dominam (ou dominam pouco) a sua língua;

- desenvolver a autonomia, a autoestima e a confiança em si próprio e nas suas competências verbais e de aprendizagem de línguas;

- desenvolver a autonomia através da interação com outros estudantes.

De acordo com a finalidade geral do estudo (ver acima), estes objetivos foram definidos em estreita articulação com os documentos reguladores deste contexto educativo preciso, a saber: Quadro Europeu Comum de Referência para as Línguas (Conselho da Europa, 2001), nível A1; programa oficial $^{8}$. De notar que este programa enfatiza uma abordagem diferenciadora e flexível das aprendizagens, que corresponda às necessidade e interesses dos alunos (Sonsoles, 2001, p. 5).

A turma era composta por alunos de Humanidades (Curso Geral de Línguas e Literaturas), com idade média de 15 anos. De acordo com a descrição disponibilizada aos professores pelo diretor da turma, a grande maioria dos alunos situava-se em ambientes da classe média e revelava hábitos de estudo, grande motivação para a escola e as aprendizagens e vontade de ingressar no ensino superior.

A tabela seguinte sintetiza as atividades realizadas durante a intervenção, distribuindo-as no tempo e relacionando-as com os recursos utilizados (de notar que vários destes recursos foram produzidos por alunos de outros grupos participantes nesta sessão Galanet).

${ }^{8} \mathrm{O}$ programa adotado nesta turma é o seguinte:

Sonsoles, F. (2001). Programa de espanhol nível de iniciação - $10^{\circ}$ Ano Formação Específica-Cursos Científico-Humanísticos de Línguas e Literaturas, de Ciências Socioeconómicas e de Ciências Sociais e Humanas. Ministério da Educação, Departamento do Ensino Secundário. 
Tabela 2: Planificação das sessões

\begin{tabular}{|c|c|c|}
\hline Sessões & Atividades & $\begin{array}{l}\text { Recursos } \\
\text { (incluindo produzidos pelos } \\
\text { alunos participantes) }\end{array}$ \\
\hline $\begin{array}{l}1^{\text {a Sessão }} \\
(135 \text { min. }) \\
18 / 02 / 2014\end{array}$ & $\begin{array}{l}\text { - Apresentação do projeto ¿Poliglota? } \\
\text { No, iplurilingüe! } \\
\text { - Descoberta da plataforma Galanet } \\
\text { - Leitura do perfil de uma equipa ita- } \\
\text { liana } \\
\text { - Redação coletiva do perfil da equipa } \\
\text { - Reconhecimento de perfis de alunos } \\
\text { apresentados na plataforma } \\
\text { - Redação do perfil individual de cada } \\
\text { aluno }\end{array}$ & $\begin{array}{l}\text { Plataforma Galanet } \\
\text { Perfil de uma equipa italiana } \\
\text { Perfil da equipa "Tugasà Beira-Ria" } \\
\text { Perfis individuais }\end{array}$ \\
\hline $\begin{array}{l}2^{\text {a }} \text { Sessão } \\
(90 \text { min. }) \\
\text { 06/03/2014 }\end{array}$ & $\begin{array}{l}\text { - Apresentação oral por cada aluno do } \\
\text { colega galanetiano mais interessante } \\
\text { - Leitura e interpretação das mensa- } \\
\text { gens escritas no passado no fórum } \\
\text { "Quel a été votre plus beau voyage?" } \\
\text { - Identificação da autoria das mensa- } \\
\text { gens em espanhol (falante nativo de } \\
\text { espanhol/aprendente de espanhol) } \\
\text { - Correção dos erros de espanhol deste } \\
\text { fórum }\end{array}$ & $\begin{array}{l}\text { Transcrições das apresentações } \\
\text { orais de "O galanetiano mais } \\
\text { interessante para mim" }\end{array}$ \\
\hline $\begin{array}{l}3^{\text {a }} \text { Sessão } \\
(135 \text { min. }) \\
11 / 03 / 2014\end{array}$ & $\begin{array}{l}\text { - Diálogo sobre os relatos das experiên- } \\
\text { cias no fórum "Quel a été votre plus } \\
\text { beau voyage?" } \\
\text { - Realização de exercícios de consoli- } \\
\text { dação do contraste entre o "pretérito } \\
\text { perfecto" e o "pretérito indefinido" } \\
\text { - Redação de um texto: "Viagem mais } \\
\text { bela" }\end{array}$ & $\begin{array}{l}\text { Relatos escritos dos alunos, } \\
\text { sobre as viagens mais belas, } \\
\text { postados no fórum "Quel a été } \\
\text { votre plus beau voyage?" }\end{array}$ \\
\hline $\begin{array}{l}4^{\text {a Sessão }} \\
(90 \text { min.) } \\
20 / 03 / 2014\end{array}$ & $\begin{array}{l}\text { - Exploração de um PowerPoint sobre } \\
\text { Barcelona (depositado pela turma de } \\
\text { Barcelona) } \\
\text { - Exposição partilhada "Y para ti, ¿qué } \\
\text { aspectos son más importantes/deter- } \\
\text { minan la calidad de una ciudad?" } \\
\text { - Realização da ficha Poliglota?, No, } \\
\text { iplurilingüe!: } \\
\text { - leitura de um texto em espanhol e } \\
\text { em catalão } \\
\text { - tradução de um parágrafo em cata- } \\
\text { lão para espanhol } \\
\text { - revisão das línguas cooficiais de } \\
\text { Espanha } \\
\text { - realização de exercícios de explo- } \\
\text { ração lexical } \\
\text { - audição de uma música em catalão }\end{array}$ & $\begin{array}{l}\text { PowerPoint De paseo por la } \\
\text { ciudad }\end{array}$ \\
\hline
\end{tabular}




\begin{tabular}{|c|c|c|}
\hline Sessões & Atividades & $\begin{array}{l}\text { Recursos } \\
\text { (incluindo produzidos pelos } \\
\text { alunos participantes) }\end{array}$ \\
\hline $\begin{array}{l}5^{\text {a Sessão }} \\
\text { (90 min.) } \\
\text { 05/05/2014 }\end{array}$ & $\begin{array}{l}\text { - Entrega a cada aluno do texto do } \\
\text { estudante por cada um selecionado } \\
\text { (apresentado oralmente à turma na } \\
\text { aula de 06/03/2014) } \\
\text { - Preenchimento de tabela: as ativi- } \\
\text { dades de ócio do meu galateniano } \\
\text { preferido (na língua original do texto } \\
\text { e em espanhol) } \\
\text { - Leitura das expressões de frequên- } \\
\text { cia presentes no manual; Redação } \\
\text { individual de algumas frases para } \\
\text { aplicação, em contexto, dessas ex- } \\
\text { pressões } \\
\text { - Visionamento do vídeo "Buen uso } \\
\text { del tiempo de ocio"(https://bit. } \\
\text { ly/1w11SHz) } \\
\text { - Debate }\end{array}$ & $\begin{array}{l}\text { Textos com os perfis dos galane- } \\
\text { tianos selecionados pelos alunos }\end{array}$ \\
\hline
\end{tabular}

Fonte: adaptado de Borges (2014, pp. 64-65).

Conforme acima referido, ao longo da intervenção, foram recolhidos vários dados com o objetivo de avaliar a sua pertinência pedagógica, face aos objetivos definidos. Neste caso concreto, a professora: gravou em áudio todas se sessões e transcreveu, posteriormente, os excertos mais significativos; recolheu os artefatos orais e escritos produzidos pelos alunos; tomou notas no seu diário de formação; aplicou um questionário final. A tabela seguinte apresenta a estrutura e objetivos desse instrumento.

Tabela 3: Estrutura e objetivos do questionário final

\begin{tabular}{|c|c|}
\hline Blocos Temáticos & Objetivos \\
\hline $\begin{array}{l}\text { Perfil linguístico do } \\
\text { aluno }\end{array}$ & $\begin{array}{l}\text { Identificar conceções dos alunos em relação às competências parciais } \\
\text { do seu perfil linguístico. }\end{array}$ \\
\hline \multirow[t]{4}{*}{ Intercompreensão } & $\begin{array}{l}\text { Identificar representações dos alunos a propósito dos conhecimentos } \\
\text { que dizem ter adquirido sobre as LR. }\end{array}$ \\
\hline & $\begin{array}{l}\text { Identificar estratégias que, na perspetiva dos alunos, foram levadas a } \\
\text { cabo para compreender as diversas LR. }\end{array}$ \\
\hline & $\begin{array}{l}\text { Identificar os conhecimentos linguísticos prévios que, na perspetiva dos } \\
\text { alunos, foram mobilizados para a compreensão das LR. }\end{array}$ \\
\hline & $\begin{array}{l}\text { Caracterizar a consciência de aprendizagem dos alunos relativa a algumas } \\
\text { particularidades da língua espanhola em relação às LR. }\end{array}$ \\
\hline
\end{tabular}




\begin{tabular}{ll}
\hline Blocos Temáticos & \multicolumn{1}{c}{ Objetivos } \\
Galanet & Recolher as avaliações dos alunos em relação ao trabalho efetuado \\
& em Galanet. \\
& Verificar a autoavaliação dos alunos a propósito da sua participação na \\
& sessão Galanet. \\
& Conferir e analisar os contactos entre os alunos e os restantes partici- \\
& pantes na sessão Galanet. \\
& Descrever as representações dos alunos em relação à atenção conce- \\
& dida às tarefas de expressão escrita potenciadas pela participação na \\
& sessão Galanet. \\
& Identificar as perceções dos alunos sobre as suas dificuldades em se \\
& exprimirem em espanhol na plataforma Galanet. \\
& Identificar conceções dos alunos sobre o interesse da prática da IC para \\
& a aprendizagem do espanhol.
\end{tabular}

Fonte: adaptado de Borges, 2014, pp. 66-67.

Estes dados foram sujeitos a análise de conteúdo triangulada, de acordo com o procedimento definido acima, tendo-se construído o sistema categorial apresentado na tabela 4.

Tabela 4: Dispositivo de análise dos dados

\begin{tabular}{|c|c|c|}
\hline Dimensões & Categorias & Subcategorias \\
\hline \multirow[t]{4}{*}{$\begin{array}{l}\text { O sujeito plurilingue e } \\
\text { a aprendizagem }\end{array}$} & $\begin{array}{l}\text { C1. Conhecimento } \\
\text { do perfil linguístico } \\
\text { do aluno }\end{array}$ & $\begin{array}{l}\text { 1.1. Desenho do repertório linguístico dos alunos } \\
\text { (com competências parciais) }\end{array}$ \\
\hline & $\begin{array}{l}\text { C2. Implicação na } \\
\text { comunicação plural }\end{array}$ & $\begin{array}{l}\text { 2.1. Curiosidade/interesse por pessoas "estran- } \\
\text { geiras" }\end{array}$ \\
\hline & & $\begin{array}{l}\text { 2.2. Abertura à diversidade de línguas minoritárias } \\
\text { 2.3. Disponibilidade para se implicar na comu- } \\
\text { nicação plural }\end{array}$ \\
\hline & & $\begin{array}{l}\text { 2.4. Sensibilidade à diversidade de usos da língua } \\
\text { em função dos seus locutores }\end{array}$ \\
\hline \multirow[t]{5}{*}{$\begin{array}{l}\text { As línguas e as cul- } \\
\text { turas }\end{array}$} & $\begin{array}{l}\text { C3. Conhecimentos } \\
\text { sobre as línguas e o } \\
\text { plurilinguismo }\end{array}$ & $\begin{array}{l}\text { 3.1. Aquisição de conhecimentos sobre a diver- } \\
\text { sidade linguística (multilinguismo) }\end{array}$ \\
\hline & C4. Conhecimentos & 4.1. Aquisição de conhecimentos sobre as LR \\
\hline & $\begin{array}{l}\text { sobre famílias de } \\
\text { línguas }\end{array}$ & $\begin{array}{l}\text { 4.2. Conhecimento de similitudes interlinguísticas } \\
\text { (correspondências lexicais entre LR) }\end{array}$ \\
\hline & & $\begin{array}{l}\text { 4.3. Conhecimento de particularidades interlin- } \\
\text { guísticas das LR em presença (particularidades } \\
\text { consonânticas) }\end{array}$ \\
\hline & $\begin{array}{l}\text { C5. Conhecimento } \\
\text { de referências cul- } \\
\text { turais }\end{array}$ & $\begin{array}{l}\text { 5.1. Disposição de referências culturais susce- } \\
\text { tíveis de estruturar o conhecimento implícito e } \\
\text { explícito do mundo (conhecimento de lugares e } \\
\text { de atividades de ócio/hábitos quotidianos) }\end{array}$ \\
\hline $\begin{array}{l}\text { Receção/Produção } \\
\text { plurilingue }\end{array}$ & $\begin{array}{l}\text { 66. Estratégias de } \\
\text { compreensão e de } \\
\text { produção escrita }\end{array}$ & $\begin{array}{l}\text { 6.1. Saber utilizar o que sabe numa língua para } \\
\text { compreender uma outra língua ou produzir numa } \\
\text { outra língua }\end{array}$ \\
\hline
\end{tabular}

Fonte: adaptado de Borges, 2014, pp. 71-73. 
Apresentamos de seguida uma sistematização dos resultados obtidos, organizada de acordo com as dimensões estruturadoras da análise (esta sistematização apoia-se em Borges, 2014, cap. III, onde se poderá encontrar grande detalhe). De notar que nesta sistematização se cruzam olhares diferenciados sobre os fenómenos em foco, nomeadamente os olhares da professora (tal como expressos nas suas notas de campo) e os dos alunos (trazidos pelas suas vozes na plataforma ou pelas respostas às atividades realizadas na aula).

\subsubsection{O sujeito plurilingue e a aprendizagem}

Saber estabelecer o seu perfil linguístico é um primeiro aspeto fundamental para a avaliação das aprendizagens realizadas pelos alunos ao longo da intervenção, na medida em que tal é revelador da sua consciência linguística. Conforme escreve De Carlo (2015), trata-se

d'amener le sujet à prendre conscience que des connaissances même partielles, fragmentaires (...) à des niveaux de compétence hétérogènes constituent un capital culturel et linguistique non négligeable. A partir de cette réflexion l'apprenant pourra par la suite regarder autour de lui pour découvrir et apprécier les ressources de son environnement, mettre en relation ses connaissances, convictions, croyances avec celles d'autres sujets et éventuellement se rendre compte du poids de ces facteurs dans la communication en contexte multilingue. (2015, p. 16).

Ora, a comparação dos perfis dos alunos registados na plataforma no início da sessão (em fevereiro) com as respostas que dão no questionário final (em abril) permite verificar, por um lado, uma assinalável expansão do perfil inicial, com a inclusão de línguas não mencionadas (o italiano e o catalão, com as quais contactaram durante a sessão Galanet), e , por outro, uma alteração das suas crenças iniciais em relação às suas competências linguísticas. Por outras palavras, no final da formação, os alunos mostram-se muito mais confiantes naquilo que são capazes de fazer com as línguas dos seus repertórios (e dos repertórios dos outros, numa perspetiva de co construção da comunicação plurilingue) e isto quer no que diz respeito à compreensão, quer à expressão (escrita e oral).

De igual modo, os alunos mostram compreender que as competências linguísticas podem ser desequilibradas, parciais, heterogéneas, reconfiguráveis na singularidade de cada encontro plurilingue, referindo, por exemplo, que compreendem agora bem o italiano mas continuam incapazes de o falar: 


\section{Sessão em aula do dia 20/03/2014 ${ }^{9}$}

P.: ¿vosotros en Galanet habéis leído mensajes en qué lenguas, además del español?

A1: italiano

A7: português

P.: $i y$ ?

A13: francês

P.: ¿habéis entendido algunos mensajes? Por ejemplo, ¿en italiano?

Todos: sí, muchos.

P.: ¿y ya alguna vez habíais aprendido italiano o sabéis hablar italiano?

Todos: ¡no!

(Borges, 2014, p. 81)

Por outro lado, os alunos revelam ter desenvolvido bastante as suas competências em espanhol, em especial no que diz respeito à expressão escrita, LR que afirmam ser aquela que melhor dominam. Assim, conforme escreve a professora no final da unidade didática, os alunos realizaram um "percurso heurístico" que Ihes desenvolveu "a autoconfiança imprescindível a qualquer individuo numa situação de contacto de línguas" (Borges, 2014, p. 80).

A implicação na comunicação plural, outra vertente de análise da dimensão "o sujeito plurilingue e a aprendizagem", pode igualmente ser observada a partir de vários indicadores. Um primeiro aspeto refere-se à curiosidade e ao interesse pelo Outro, locutor de uma outra LR mais ou menos sentida como próxima e fácil, mais ou menos familiar, que a turma revela relativamente aos seus colegas das outras equipas. De acordo com o diário de bordo da professora, as primeiras evidências desta curiosidade, já notada noutras sessões de IC desta natureza (Araújo e Sá, De Carlo, \& Melo-Pfeifer, 2010; Araújo e Sá \& Espinha, 2018), manifestam-se logo na atividade "apresentação oral à turma do galateniano mais interessante" (ver tabela 2, sessão 1 ), aquando do primeiro contacto dos alunos com os seus companheiros de viagem, contacto este ao qual reagiram com "euforia e excitação" (cf. Diário de bordo, Borges, 2014, anexo 4). Estes sentimentos foram provocados, em especial, pelo visionamento de fotos dos perfis individuais, pelo plurilinguismo da plataforma e pelas expetativas criadas relativamente ao trabalho de projeto que se seguiria. Interessante notar, como sinal de interesse por um outro diverso que se quer conhecer melhor, que nenhum dos alunos da turma selecionou para apresentação um galateniano da sua própria nacionalidade, muito embora na sessão tivessem participado três turmas de outras escolas em Portugal (ver tabela 1).Com efeito, a grande maioria optou pelos colegas

9 Todos os exemplos são aqui reproduzidos na sua forma original, tal como devolvidos nos relatórios-fonte (Borges, 2014; Ferreira, 2014). 
italianos, aqueles que publicaram textos em línguas consideradas menos conhecidas (línguas estas, aliás, nem sequer referidas nos perfis individuais, ver acima).

Um aspeto curioso a notar é o facto de os alunos terem incluído, nas suas apresentações orais, informações sobre os colegas que não constavam nos perfis por eles depositados; tal indicia que recolheram estas informações ou através de contactos diretos e espontâneos fora da plataforma, ou da leitura de outras mensagens depositadas nos fóruns, comportamentos estes que revelam o seu forte grau de implicação nestas trocas plurilingues e a sua disponibilidade para elas. Corroborando esta interpretação, quando inquiridos no questionário final a este respeito, uma percentagem significativa dos estudantes (66\%) afirma ter-se implicado nesta comunicação plurilingue, apontando como razões fundamentais interesses comuns (música, televisão, atividades várias de tempos livres) e curiosidade intercultural.

Ainda nesta mesma linha, importa realçar a forte implicação dos alunos na redação dos textos que postaram na plataforma. Trata-se globalmente de textos escritos de elevada qualidade para alunos de iniciação (A1), bastante detalhados no conteúdo, nos quais não apenas procuram revelar-se aos colegas, seus companheiros de projeto, mas ainda fazê-lo com correção, procurando dar de si uma boa imagem enquanto aprendentes de línguas e locutores de espanhol. O texto seguinte exemplifica esta implicação na produção escrita:

¡Hola a todos; Yo soy portuguesa y me gusta mucho viajar por mi país. Aunque pequeño, Portugal tiene sitios muy bonitos, desde el Norte al Sur. Ya he visitado muchas ciudades portuguesas, pero las ciudades con historia me encantan porque a mí me gusta mucho imaginar cómo sería vivir otrora. Visito las grandes ciudades, pero el interior para mí es mucho más bonito.

Mi viaje favorito fue a Manta Rota, Tavira, Algarve porque estuve en una casa muy cerca de la 87 playa y el agua de la playa era muy tranquila y limpia. También me gustó mucho ir a Marvão, Guimarães, Viseu, Porto y Lisboa. Mi viaje de sueño es a Madrid porque tengo una admiración por la capital y por los españoles, en especial, por Maxi lglesias; pero también me gustaría ir a Puerto Rico, pues me encanta América Latina por la Salsa, la Bachata y el Reggaeton.

¡Adiós! ¡Visitad Portugal!

(Borges, 2014, p. 86-87)

Inquiridos no questionário final sobre a atenção concedida a estas tarefas, todos os alunos declararam ter investido bastante na formulação, reformulação, verificação e tradução dos seus artefactos escritos. 
Uma nota final para referir a abertura às línguas minoritárias proporcionada por esta participação, manifestada em especial nos momentos em que se falou sobre as línguas cooficiais de Espanha (ver tabela 2, sessão 4), momentos estes motivados pela participação de uma turma de Barcelona e pela audição (seguida de tradução) de músicas em catalão divulgadas por esta turma.

\author{
Sessão em aula do dia 20/03/2014 \\ vamos a discutir sobre el contenido. ¿Vale? \\ [silencio] \\ 58'36 [ouvem-se sorrisos e vários ruídos de fundo] \\ P.: Lia está riéndose... ¿qué pasa? \\ A1: isto é catalão! \\ P.: ¿conocéis? \\ Alunos: mais ou menos... \\ A1: é giro, stôra! \\ (Borges, 2014, p. 83, sublinhado da autora)
}

P.: entonces tenemos ahí un texto con mensajes de un chico de Barcelona. Vamos a leer con atención los dos primeros párrafos en silencio y luego

Este interesse, que se manteve ao longo da sessão e envolveu outras línguas (como o basco), motivou ainda, da parte de alguns alunos, o desejo de aprender catalão:

A4: ó stôra, nós vimos no Galanet a versão catalã da música "mi barba tiene tres pelos". Como é que se lê "La meva barba té 3 pèls?" Onde é que podíamos aprender catalão? (Borges, 2014, p. 84).

\title{
3.1.2 As línguas e as culturas
}

Ao longo da experiência de formação, vários foram os conhecimentos sobre as línguas e culturas desenvolvidos pelos alunos, tal como eles próprios reconheceram, quer no questionário final, quer durantes as aulas, destacando-se aqueles referentes à diversidade linguística, às famílias de línguas (com enfoque nas românicas) e ao plurilinguismo.

No âmbito dos objetivos desta intervenção educativa, importa salientar em especial a aquisição de conhecimentos específicos sobre factos linguísticos e modos de funcionamento das línguas, com incidência no espanhol, reveladores de uma consciência metalinguística em construção, fortemente potenciada pelas atividades propostas, tais como: similitudes/ diferenças interlinguísticas (correspondências lexicais e sintáticas entre LR, 
por exemplo) e particularidades interlinguísticas (exemplo: consonânticas, da língua espanhola). Abaixo ilustra-se uma interação em sala de aula reveladora deste conhecimento:

\section{Sessão em aula do dia 11/03/2014}

[após os exercícios de revisão/consolidação do contraste entre o pretérito perfecto/indefinido e a leitura de algumas mensagens escritas no fórum "Quel a été votre plus beau voyage?"]

P.: seguimos a ver otros mensajes. Este está en francés. Como veis, la construcción del pasado sigue la misma construcción del pretérito perfecto en español. ¿Cómo es?

A1: aquí tiene un verbo auxiliar, avoir, y un participio... "Mon plus beau voyage a été a Londres il y a trois ans"

P.: ¿y cómo es el pretérito perfecto en español?

A1: com o verbo auxiliar haber mais o particípio do verbo principal

P.: ¿un ejemplo en español?

A1: él ha comido una manzana

A9: ó stôra, aqui, em italiano, a construção também é a mesma... Però ho veramente visto "Iialtra metà del mondo»: squali, mante, trigoni, barracuda...testuggini marine...e tanti coralli stupendi!

P: sí, podemos ver... ilo mismo! ¿y cómo podríamos traducir el italiano "ho veramente visto" al español?

A9: ¿he verdaderamente visto?

P: ¡Muy bien!

(Borges, 2014, pp. 94-95)

Nestas atividades de comparação interlinguística ganha destaque um enfoque sobre a língua espanhola, disciplina curricular em cujas aulas foram realizadas. Aliás, em vários momentos, o professor propõe a identificação de particularidades do espanhol, a vários níveis do funcionamento linguístico, mostrando-se os alunos capazes de responder e de explorar diferenças e semelhanças entre as línguas em presença.

Os conhecimentos adquiridos são também referentes a aspetos culturais, permitindo aos alunos partilhar e discutir com outros jovens a frequência de lugares, atividades de tempos-livres e hábitos quotidianos, entre outros.

\subsubsection{Receção/produção plurilingue}

No que diz agora respeito às atividades de linguagem, aquelas que foram propostas pela professora impeliram os alunos a mobilizar os seus recursos verbais, tal como, a utilizar o que sabem numa língua para 
compreender uma outra ou produzir numa outra. Por exemplo, na atividade "construção do perfil galanetiano mais interessante", os alunos tiveram que mobilizar conhecimentos não apenas nas línguas em que se encontravam escritos os perfis selecionados (italiano, francês, espanhol, catalão), mas ainda em espanhol, língua de aprendizagem (para apresentação oral à turma). De igual modo, as atividades de tradução (por exemplo, de catalão para espanhol) e de preenchimento de tabelas-síntese sobre as atividades de ócio dos galaneteanos (ver tabela 2), favoreceram a mobilização de estratégias de compreensão e de expressão escrita, tais como: observar/analisar as formas e os funcionamentos linguísticos; identificar as línguas através de expressões/ palavras conhecidas; reconhecer a proximidade lexical. Também nas respostas aos questionários, os alunos referem estratégias de acesso ao sentido como: identificação de ideias-chave; leitura frase a frase; leitura global; atenção ao contexto; procura de semelhanças lexicais. O professor, nas suas notas de campo, identifica como estratégia preponderante "a reconstrução do significado a partir do reconhecimento das palavras até chegar a frases ou parágrafos" (Borges, 2014, p. 105).

Relevante é assinalar que os alunos, ainda nas respostas ao questionário, revelaram a consciência de terem transferido conhecimentos específicos de umas línguas para as outras neste processo de acesso ao significado, revelando plena consciência do valor dos seus conhecimentos nas línguas espanhola e portuguesa para compreenderem textos em italiano, catalão ou francês.

Em síntese, a avaliação desta experiência pedagógica parece apontar para o contributo que uma abordagem da IC em contexto escolar, no seio das disciplinas linguísticas, pode dar para o projeto de ensino-aprendizagem do ELE, permitindo pensar o currículo desta disciplina numa perspetiva simultaneamente mais individualizada (adaptada a cada aluno e a cada grupo), mais partilhada e implicada (envolvendo professor e alunos em interações mais significativas, construídas em torno dos seus interesses e motivações) e mais holística e integrada (incitando a "une culture de curriculum commune à travers toutes les langues" (Egli Cuenat, 2009, p. 3). Uma perspetiva, em suma, favorecedora do desenvolvimento da competência plurilingue e intercultural dos aprendentes, nas suas múltiplas componentes, tal como preconizado nos documentos reguladores destas práticas profissionais. 


\subsection{Caso 2 - A IC numa turma de continuação de Espanhol, percurso} profissional

O segundo estudo foi realizado numa turma de Espanhol, $10 .^{\circ}$ ano, nível 4, da via profissional (disciplina integrada na Componente de Formação Sociocultural), de uma escola secundária da região de Coimbra.

De acordo com informação constante no dossier da turma, esta era composta por 8 alunos ( 6 do género masculino e 2 do género feminino, sendo 4 do Curso Técnico de Manutenção Industrial Eletromecânica e os restantes do Curso de Técnico de Multimédia), com idades entre os 15 e 18 anos, provenientes de um extrato social e económico baixo, que apresentavam um percurso escolar com situações de abandono e de retenção e manifestavam baixas expetativas relativamente ao seu futuro académico. Embora o nível esperado fosse B1, o nível atribuído através do teste diagnóstico foi A2. Na sua biografia linguística inicial, cuja elaboração foi proposta pela professora estagiária, os alunos revelaram poucos contactos com as línguas e pouca motivação para as aprender e usar.

Esta disciplina, inserida, conforme referido, num percurso profissional, rege-se por um programa ${ }^{10}$ que define módulos de formação e privilegia uma metodologia orientada para a ação, tendo em vista a realização de tarefas significativas que levem o aluno a utilizar a língua-alvo em situações autênticas e a desenvolver a sua competência comunicativa, nas suas várias vertentes, aceitando competências parciais, únicas a cada indivíduo e situadas no tempo e no espaço. Refere, também, que o professor deve privilegiar a reflexão sobre as diferenças e semelhanças entre o português e o espanhol e fomentar o desenvolvimento de estratégias que auxiliem o aluno a superar as suas dificuldades (Ministério da Educação, 2006). Esta intervenção, considerada relevante face a estas orientações curriculares estruturantes, foi integrada no Módulo 3, "Juventude e Cidadania - cidadãos europeus", tendo ocupado sete sessões de 90 minutos e uma de 45 minutos, conforme se esquematiza na tabela 5 .

${ }^{10}$ Ministério da Educação - Direção-Geral de Orientação Vocacional (2006). Programa Componente de Formação Sociocultural Disciplina de Espanhol. Recuperado de https://bit.ly/34bgbAP. 
Tabela 5: Planificação global das sessões

\begin{tabular}{|c|c|c|}
\hline Sessões & Atividades & Objetivos específicos \\
\hline $\begin{array}{l}\text { 1. }^{\text {a Sessão }} \\
\text { (90min.) } \\
\text { 10/02/2014 }\end{array}$ & $\begin{array}{l}\text { - Comentário de um cartoon sobre } \\
\text { o trabalho precário dos jovens } \\
\text { em Espanha. } \\
\text { - Leitura e compreensão de um } \\
\text { texto sobre os direitos dos jovens } \\
\text { (espanhóis) enquanto cidadãos } \\
\text { europeus. } \\
\text { - Webquest sobre a UE: países, } \\
\text { política linguística, direitos } \\
\text { fundamentais dos cidadãos, } \\
\text { programas para estudantes. } \\
\text { - Introdução da sessão “Poli- } \\
\text { glotta? No, plurilingue!': viagem } \\
\text { pela plataforma e elaboração do } \\
\text { perfil de equipa. } \\
\text { - Jogo interativo “iVamos a explo- } \\
\text { rar Europa!”. }\end{array}$ & $\begin{array}{l}\text { - Expressar a opinião sobre o tema } \\
\text { do desemprego e trabalho precá- } \\
\text { rio entre os jovens. } \\
\text { - Contrastar a situação laboral dos } \\
\text { jovens espanhóis com os portu- } \\
\text { gueses. } \\
\text { - Refletir sobre os seus direitos } \\
\text { enquanto jovens cidadãos euro- } \\
\text { peus. } \\
\text { - Desenvolver a consciência da } \\
\text { importância da EU como garante } \\
\text { dos direitos dos cidadãos euro- } \\
\text { peus. } \\
\text { - Conhecer a plataforma Galanet. } \\
\text { - Envolver-se no projeto através do } \\
\text { contacto com as equipas parti- } \\
\text { cipantes e a elaboração do perfil } \\
\text { de equipa. } \\
\text { - Adquirir/Rever conhecimentos } \\
\text { históricos, culturais e geográficos } \\
\text { sobre os países europeus. }\end{array}$ \\
\hline
\end{tabular}

\section{2. ${ }^{a}$ Sessão}

(90 min.)

$11 / 02 / 2014$
- Visionamento de dois excertos do filme "Un Franco, 14 Pesetas".

- Resolução de uma ficha de trabalho sobre os excertos.

- Reflexão sobre como agir num contexto linguístico e cultural distinto do seu.

- Participação na plataforma Galanet: preenchimento do perfil individual.
- Observar estratégias usadas na interação entre falantes de línguas diferentes que desconhecem a língua dos seus interlocutores.

- Reconhecer barreiras linguísticas na comunicação verbal entre falantes de línguas diferentes.

- Refletir sobre formas de interagir em situação de contacto entre falantes de línguas e culturas diferentes.

- Participar ativamente nas tarefas propostas no âmbito do desenvolvimento de um projeto comum.

- Comunicar com falantes romanófonos utilizando as potencialidades oferecidas pela proximidade linguística. 


\begin{tabular}{|c|c|c|}
\hline Sessões & Atividades & Objetivos específicos \\
\hline $\begin{array}{l}\text { 3. }^{a} \text { Sessão } \\
\text { (90 min.) } \\
\text { 17/02/2014 }\end{array}$ & $\begin{array}{l}\text { - Leitura e análise de excertos de } \\
\text { um fórum e de um chat retirados } \\
\text { de sessões anteriores na plata- } \\
\text { forma Galanet. } \\
\text { - Exercício de expressão escrita } \\
\text { sobre o grau de familiaridade } \\
\text { com a comunicação virtual e as } \\
\text { vantagens das interações pluri- } \\
\text { lingues virtuais. }\end{array}$ & $\begin{array}{l}\text { - Identificar os tipos de texto e } \\
\text { reconhecer as particularidades } \\
\text { da comunicação virtual síncrona } \\
\text { e assíncrona. } \\
\text { - Identificar manifestações intera- } \\
\text { tivas da competência plurilingue. } \\
\text { - Refletir sobre os perigos dos } \\
\text { falsos perfis na Internet. } \\
\text { - Produzir um texto escrito sobre } \\
\text { a sua familiaridade com a comu- } \\
\text { nicação virtual e as vantagens } \\
\text { das interações plurilingues vir- } \\
\text { tuais, superando as dificuldades } \\
\text { mediante o recurso a diversas } \\
\text { ferramentas }\end{array}$ \\
\hline $\begin{array}{l}4^{a}{ }^{a} \text { Sessão } \\
\text { (90 min.) } \\
\text { 18/02/2014 }\end{array}$ & $\begin{array}{l}\text { - Visionamento da reportagem } \\
\text { "Un día en la vida de un } \\
\text { Erasmus". } \\
\text { - Resolução de uma ficha de } \\
\text { trabalho sobre o vídeo. } \\
\text { - Leitura e compreensão de excer- } \\
\text { tos de um fórum de uma sessão } \\
\text { na plataforma Galanet. } \\
\text { - Revisão dos tempos verbais do } \\
\text { passado: pretérito indefinido e } \\
\text { pretérito imperfecto. } \\
\text { - Simulação de uma entrevista a } \\
\text { personalidades que dão nome } \\
\text { a programas de formação e de } \\
\text { estudo da UE. }\end{array}$ & $\begin{array}{l}\text { - Refletir sobre a importância de } \\
\text { conhecer as particularidades de } \\
\text { hábitos e costumes de países } \\
\text { diferentes do nosso. } \\
\text { - Refletir sobre as possibilidades } \\
\text { de comunicação num contexto } \\
\text { no qual se falam línguas dife- } \\
\text { rentes. } \\
\text { - Inferir as regras de formação e } \\
\text { uso do pretérito imperfecto e do } \\
\text { pretérito indefinido. } \\
\text { - Utilizar o pretérito imperfecto e o } \\
\text { pretérito indefinido em exercícios } \\
\text { de prática controlada. }\end{array}$ \\
\hline $\begin{array}{l}\text { 5. }{ }^{a} \text { Sessão } \\
\text { (45 min.) } \\
\text { 25/02/2014 }\end{array}$ & $\begin{array}{l}\text { - Eleição de um dos temas } \\
\text { propostos em "Mi equipo", } \\
\text { "Elección del tema”, na sessão } \\
\text { Galanet. } \\
\text { - } \text { Realização de uma ficha de tra- } \\
\text { balho sobre estratégias em IC. } \\
\text { - Exercício de expressão escrita } \\
\text { para publicar num fórum. }\end{array}$ & $\begin{array}{l}\text { - Participar nas tarefas propostas } \\
\text { no âmbito de um projeto comum. } \\
\text { - Comunicar com falantes romanó- } \\
\text { fonos utilizando as potencialida- } \\
\text { des oferecidas pela proximidade } \\
\text { linguística. } \\
\text { - Desenvolver a consciência meta- } \\
\text { linguística. } \\
\text { - Produzir um texto breve e } \\
\text { coerente, aplicando os tempos } \\
\text { do passado e superando as di- } \\
\text { ficuldades mediante o uso de } \\
\text { diversas ferramentas. }\end{array}$ \\
\hline
\end{tabular}




\begin{tabular}{|c|c|c|}
\hline Sessões & Atividades & Objetivos específicos \\
\hline $\begin{array}{l}\text { 6. }^{\text {a Sessão }} \\
(90 \text { min.) } \\
10 / 03 / 2014\end{array}$ & $\begin{array}{l}\text { - Leitura e análise de um texto } \\
\text { sobre como melhorar a expres- } \\
\text { são escrita. } \\
\text { - Revisão de expressões de obri- } \\
\text { gação/recomendação. } \\
\text { - Exercício de expressão escrita } \\
\text { - reescrita de textos pessoais } \\
\text { publicados nos fóruns da sessão } \\
\text { Galanet. } \\
\text { - Participação na sessão "Poli- } \\
\text { glotta? No, plurilingue!": eleição } \\
\text { de um dos temas propostos nos } \\
\text { fóruns da fase 2, "Tormenta de } \\
\text { ideas". } \\
\text { - Realização de uma ficha de tra- } \\
\text { balho sobre estratégias de IC. }\end{array}$ & $\begin{array}{l}\text { - Refletir sobre a sua atitude } \\
\text { perante a expressão escrita em } \\
\text { ELE. } \\
\text { - Inferir regras de formação e uso } \\
\text { da expressão de obrigação pes- } \\
\text { soal e impessoal. } \\
\text { - Utilizar as expressões de obri- } \\
\text { gação revistas em exercícios de } \\
\text { prática controlada. } \\
\text { - Produzir um texto breve e } \\
\text { coerente, superando as dificulda- } \\
\text { des mediante o uso de diversas } \\
\text { ferramentas. } \\
\text { - Participar no desenvolvimento de } \\
\text { um projeto comum. } \\
\text { - Fazer uma leitura seletiva de tex- } \\
\text { tos em LR para encontrar infor- } \\
\text { mação específica e desenvolver a } \\
\text { competência plurilingue. }\end{array}$ \\
\hline $\begin{array}{l}\text { 7. a Sessão } \\
\text { (90min.) } \\
1 / 04 / 2014\end{array}$ & $\begin{array}{l}\text { - Leitura de um texto com indi- } \\
\text { cações sobre a realização e ava- } \\
\text { liação dos trabalhos a integrar } \\
\text { o dossiê de imprensa da sessão } \\
\text { "Poliglotta? No, plurilingue!'. } \\
\text { - Redação dos trabalhos finais. } \\
\text { - Preenchimento do inquérito } \\
\text { final. }\end{array}$ & $\begin{array}{l}\text { - Participar no desenvolvimento de } \\
\text { um projeto comum. } \\
\text { - Manejar diferentes fontes de } \\
\text { informação. } \\
\text { - Fazer uma leitura seletiva de } \\
\text { textos/vídeos para encontrar } \\
\text { informação específica. } \\
\text { - Produzir um trabalho escrito, su- } \\
\text { perando as dificuldades median- } \\
\text { te o uso de diversas ferramentas. } \\
\text { - Adotar uma perspetiva de (auto) } \\
\text { avaliação sobre as suas aprendi- } \\
\text { zagens, indicando ganhos, difi- } \\
\text { culdades e objetivos atingidos. }\end{array}$ \\
\hline
\end{tabular}

Fonte: adaptado de Ferreira, 2014, pp. 55-58.

Os dados recolhidos para a avaliação da intervenção consistiram em: produções dos alunos (fichas de trabalho, produções escritas); interações na plataforma Galanet (perfil da turma, perfis individuais dos alunos, participações nos fóruns e chats); inquéritos (biografia linguística e inquérito final).

A tabela seguinte apresenta a estrutura e objetivos do inquérito final. 
Tabela 6: Estrutura e objetivos do questionário final

\section{Blocos Temáticos Objetivos}

I. Autoavaliar a participação 1.1. Identificar as atividades mais/menos apreciadas pelos alunos. na sessão "Poliglotta? No, plurilingue!"

1.2. Verificar a existência de aspetos que condicionassem a participação na sessão.

1.3. Saber o grau de facilidade/dificuldade da resolução das fichas "Primeros pasos en la Intercomprensión".

1.4. Saber o grau de facilidade/dificuldade na compreensão das línguas usadas na sessão.

1.5. Identificar as estratégias mais/menos utilizadas na compreensão das línguas que não conheciam.

1.6. Identificar mais-valias adquiridas percebidas com a participação no projeto.

1.7. Averiguar a disponibilidade para participar em outra sessão.

II. Averiguar eventuaisganhos 2.1. Identificar possíveis objetivos do programa atingidos no percebidos na aprendizagem âmbito da unidade didática "Cidadãos europeus".

e desenvolvimento de com- 2.2 Identificar as atividades mais/menos apreciadas ao longo petências em ELE. da unidade didática "Cidadãos europeus".

Fonte: Ferreira, 2014, pp. 70-71.

O dispositivo de análise, construído, como o do estudo anterior, na interação entre o esquema genérico organizador proposto pelo REFIC e a leitura indiciária dos dados naturalistas recolhidos, é apresentado na tabela 7.

Tabela 7: Dispositivo de análise

\begin{tabular}{|c|c|c|}
\hline Dimensões & Categorias & Subcategorias \\
\hline \multirow[t]{4}{*}{$\begin{array}{l}\text { O sujeito plurilingue e a apren- } \\
\text { dizagem }\end{array}$} & $\begin{array}{l}\mathrm{C} 1 \text {. Conhecero seu } \\
\text { perfil linguístico eo seu }\end{array}$ & $\begin{array}{l}\text { 1. 1. Saber estabelecer o seu perfil } \\
\text { linguístico }\end{array}$ \\
\hline & $\begin{array}{l}\text { ambiente linguístico- } \\
\text {-cultural }\end{array}$ & $\begin{array}{l}\text { 1.2. Conhecer o seu ambiente } \\
\text { linguístico-cultural }\end{array}$ \\
\hline & $\begin{array}{l}\text { C2. Desenvolver atitudes } \\
\text { favoráveis à aprendiza- }\end{array}$ & $\begin{array}{l}\text { 2. } 1 \text {. Abrir-se à diversidade lin- } \\
\text { guística e cultural }\end{array}$ \\
\hline & $\begin{array}{l}\text { gem plurilingue (elemen- } \\
\text { tos afetivos) }\end{array}$ & 2.2. Saber interagir com os outros \\
\hline As línguas e as culturas & $\begin{array}{l}\text { C3. Ter conhecimentos } \\
\text { sobre línguas aparen- } \\
\text { tadas }\end{array}$ & $\begin{array}{l}\text { 3.1. Saber comparar as línguas } \\
\text { para reconhecer as principais } \\
\text { semelhanças linguísticas }\end{array}$ \\
\hline \multirow[t]{2}{*}{ A compreensão escrita } & $\begin{array}{l}\text { C4. Mobilizar estratégias } \\
\text { de IC }\end{array}$ & $\begin{array}{l}\text { 4.1. Apoiar-se em elementos facil- } \\
\text { mente identificáveis }\end{array}$ \\
\hline & & $\begin{array}{l}\text { 4.2. Deduzir o significado de pala- } \\
\text { vras a partir de correspondências } \\
\text { gráficas e fonológicas }\end{array}$ \\
\hline \multirow[t]{2}{*}{ A interação plurilingue } & $\begin{array}{l}\text { C5. Participar numa } \\
\text { interação plurilingue }\end{array}$ & $\begin{array}{l}\text { 5.1. Saber inserir-se numa dinâ- } \\
\text { mica discursiva de intercâmbio }\end{array}$ \\
\hline & & $\begin{array}{l}\text { 5.2. Saber gerir problemas de } \\
\text { compreensão na interação }\end{array}$ \\
\hline
\end{tabular}

Fonte: Ferreira, 2014, pp. 72-73. 
De seguida apresenta-se, nos seus eixos estruturantes, uma síntese dos resultados obtidos, remetendo mais uma vez para o relatório da investigação-ação onde se encontra uma apresentação detalhada (Ferreira, 2014, cap. 3).

\subsubsection{O sujeito plurilingue a aprendizagem}

A análise da informação inicial recolhida nas biografias linguísticas revela que a generalidade destes alunos não mostra consciência dos seus contactos com as línguas e culturas, referindo um perfil e ambiente linguístico aparentemente extremamente limitado, em particular às línguas de escolarização, as únicas referidas e nas quais os alunos consideram ter alguma competência. Os alunos apresentam ainda, globalmente, expetativas muito baixas quer relativamente às suas competências de compreensão e produção noutras línguas, quer à sua participação antevista na formação Galanet, para a qual não se mostram motivados (No suelo mucho de participar en chats, depende se tiengo tiempo participo se no tiengo tiempo no participico - A5; Ferreira, 2014, p. 78).

Contudo, gradualmente, ao longo da sessão, foi possível detetar mudanças positivas nalguns alunos, desde logo aquando da redação dos perfis linguísticos individuais (onde indicam novas possibilidades de relação com as línguas), e depois no envolvimento em trocas plurilingues espontâneas na plataforma, com algumas misturas linguísticas que revelam a implicação na comunicação. A vontade de aprender línguas ( puedo aprender otras lenguas, abrir mis horizontes en questión de lenguas, - A3; Ferreira, 2014, p. 78) e o desejo de conhecer o Outro, de se dar a conhecer, de partilhar, de fazer coletivo, são com efeito manifestos nestes dados. Exemplos muito significativos desta nova atitude de implicação é o facto de os alunos fazerem propostas ao grupo, tomando a iniciativa de propor temas comuns a desenvolver ao longo da sessão e envolvendo-se ativamente na realização das tarefas, como demonstra o extrato seguinte:

OLÁ!!! Como está a chegar a Páscoa podíamos falar sobre os vários típicos pratos o nosso país, cada um falava dos pratos do seus pais relacionados com a pascoa, mas é só uma sugestão. Nada de mais. Obrigado.

(A1 - Fórum Alla scoperta dei piatti regional; Ferreira, 2014, p. 81)

De referir contudo, em contraste com a turma anterior, que raramente os alunos recorrem ao ELE para comunicar, apensar de tal Ihes ter sido solicitado pelas professoras (ver acima), mostrando relutância em usar esta língua para efeitos de comunicação. 


\subsubsection{As línguas e as culturas}

Ao longo dos 3 meses em que decorreu esta formação, foi possível identificar sinais de que os alunos conseguiram reconhecer semelhanças, diferenças e especificidades nas línguas em presença, ao mesmo tempo em que se apoiaram nos seus repertórios linguístico-comunicativos, no contexto verbal e nas regularidades interlinguísticas (lexicais e sintáticas) detetadas para participar nas atividades propostas. Note-se, por exemplo, esta interação de uma das alunas (D.L) com a professora italiana (CarlaN):

[18:30:17][CarlaN] Riesci a capire la nostra conversazione in italiano?

[18:30:58][D.L] Consigo entender mais ou menos

[18:31:28][CarlaN] Brava D.! hai notato come l'italiano e il portoghese nello scritto sono vicini?

[18:32:24][D.L] Sim, sao muito parecidos... ambos derivam do latin, nao é? (Excerto do chat realizado a 17 de fevereiro; Ferreira, 2014, p. 84)

De igual modo, quando, no final da sessão, são questionados sobre as línguas que consideram mais e menos fáceis de compreender, e embora o espanhol surja como aquela mais referida como língua fácil, os alunos mencionam agora também o catalão e o italiano, línguas estas que estavam completamente ocultas no início da sessão.

\subsubsection{A compreensão escrita}

Nas respostas às fichas de trabalho e ao inquérito final, os alunos referem estratégias que mobilizaram para compreender os enunciados escritos nas línguas da sessão, o que indicia o desenvolvimento da sua competência metacognitiva. Entre elas, o recurso à língua materna e ao espanhol, língua em estudo, são as mais referidas, mas surgem outras, tais como se verifica na tabela seguinte, onde os alunos explicitam e exemplificam as estratégias mobilizadas na compreensão dos perfis depositados pelos colegas na plataforma.

Tabela 8: Estratégias e respetiva exemplificação referidas pelos alunos na compreensão dos perfis do grupo Galanet

\begin{tabular}{ll}
\hline \multicolumn{1}{c}{ Estrategias } & \multicolumn{1}{c}{ Ejemplos } \\
\hline Palabras transparentes & A1- "Agradecer" \\
& A2- "Amigos, nature" \\
& A5 - "Mi, Amo, inglese, Francese, italieno, vivo, música, \\
& tengo, tempo, libro..., vivo" \\
& A6 - "Fotografía, amigos, compras" \\
& A7- "Francese-Spagnolo-Inglese-Portoghese Musica" \\
A8- "Nature"
\end{tabular}




\begin{tabular}{ll}
\hline \multicolumn{1}{c}{ Estrategias } & \multicolumn{1}{c}{ Ejemplos } \\
\hline Deducción a partir del contexto & A1- "Meus amics" \\
& A3- "Meus amics" \\
& A7- "Ma sono nato" \\
\hline Conocimiento de otras lenguas & A1- "Parlo catalá" \\
(indica cuáles) & A3- "Parlo catalá" \\
Conocimientos culturales, de historia & A7- "Visítatelo (español)" \\
y de geografía & A2- "Red Hot Cilli Peppers" \\
& A8- "Red Hot Cilli Peppers" \\
& A7- "Macklemare" \\
\hline Extranjerismos & A2- "Rock" \\
& A8- "Rock" \\
& A5- "Blog, fashion, rock" \\
& A7- "Rock; blog; Fashion" \\
\hline
\end{tabular}

Fonte: Ferreira, 2014, p. 90.

\subsubsection{A interação plurilingue}

A observação das dinâmicas plurilingues em que participaram estes alunos, síncronas (nos chats) e assíncronas (nos fóruns), tornam visível o seu sentimento de pertença a esta comunidade de comunicação e de aprendizagem da IC. Na verdade, são percetíveis múltiplas marcas descritas na literatura de prática interacional da IC (tais como a frequência de rituais relacionais, como os rituais de cortesia ou de figuração, expressões de auto-estima, votos de reencontro, smileys, pontuação expressiva, interjeições) (Araújo e Sá, 2013), reveladoras da vontade de construir relações dentro desta comunidade mas, mais ainda, de aprender com ela:

[21:01:54][CarlaN] Ola D.

[21:02:53][D.L] Ola CarlaN :)

[21:07:50][GiusCo] Hola D., que tal? estàs bien?

[21:09:18][D.L] Bem, obrigada...e contigo GiuCo?

[21:09:41][GiusCo] Estoy bastante bien D.L,Gracias

(Excerto do chat realizado a 6 de março; Ferreira, 2014, pp. 95-96)

Muito obrigado, acho que trabalhamos bem foi uma esperiencia muito interessante e quem sabe se um dia não nos vemos por ai :D Mais uma vez obrigado. Resto de um bom trabalho. Beijos e abraços (mensagem no fórum, 22/04/14 13:10; Ferreira, 2014, p. 93)

Este sentimento de pertença, aliás, é comum a alunos de outras equipas desta sessão de formação, tal como evidenciado no estudo de Araújo e Sá e Espinha (2018). 
Sintetizando estes resultados, e considerando o conceito didático em que assenta a intervenção pedagógica analisada (a IC enquanto processo de co construção de sentido entre falantes de línguas diferentes, através da mobilização - e consequente desenvolvimento - de conhecimentos prévios, competências e disposições), verifica-se que, ao longo das sessões, estes alunos, apesar da sua atitude inicial descomprometida, foram deixando indícios que apontam para o seu crescente envolvimento nas atividades propostas. Em especial, notou-se o desenvolvimento da sua consciência, quer das aprendizagens efetuadas, quer dos recursos mobilizados, bem como da compreensão das potencialidades de um projeto como este para o seu percurso de aprendizagem de línguas em geral e do ELE em particular. A intervenção contribuiu ainda para que os alunos se apercebessem das possibilidades comunicativas entre falantes de línguas aparentemente desconhecidas e desenvolvessem estratégias para as explorar no processo de construção do sentido.

\section{Discussão e notas finais}

Concluo este texto retomando as questões iniciais que o ditaram, relacionadas com a circulação do conceito de IC em contextos educativos formais ou, por outras palavras, as configurações que ele adquire quando utilizado pelos professores para pensar e agir curricularmente (Roldão, 2006). Esta questão é bastante complexa, quer devido à complexidade da própria noção que Ihe subjaz (a de currículo), quer devido à sua abrangência, em múltiplos níveis de ação que se regulam reciprocamente. Por outras palavras, e como claramente colocam Beacco et al. (2010, cap. 1), conceber e colocar em prática um currículo plurilingue e intercultural envolve um conjunto de ações que se situam em diferentes níveis do sistema educativo, desde o nível supra (internacional), ao nacional (sistemas educativos e programas), incluindo ainda a escola (nível meso), a turma (micro) e os sujeitos (nano). Neste estudo, procurámos ter em pano de fundo estes vários níveis em interação, mas a centração sobre o professor, a turma, os sujeitos e as suas possibilidades conjuntas, é evidente. Este será pois um elemento a considerar nestas notas finais.

Embora, como referido, a noção de currículo seja de grande complexidade e este artigo não seja, por razões evidentes, um espaço para a discutir, a forma como os professores se apropriaram, nos estudos relatados, da noção de IC, permitiu compreender o currículo como um jogo de significações (Tadeu da Silva, 2006) fortemente contextualizado. Por outras palavras, é evidente a forma diferenciada como cada professor, em interação com a turma, construiu a sua proposta em IC, mostrando que o currículo é 
uma "trajetória, viagem, percurso (...) autobiografia, nossa vida" (Tadeu da Silva, 1999), ou seja, é uma construção interpessoal, feita pelos sujeitos através das suas experiências educativas, e que não se esgota nem termina na escolaridade (Beacco et al., 2010). Ressalta assim, nesta apropriação singular, que a IC pode ser um conceito que inspira a inovação, ou uma relação mais plástica, mais experiencial, mais essencial, mais quotidiana, do professor com os alunos, ou mesmo, antes de tudo, do professor consigo próprio. Como escreve uma das professoras, esta experiência

foi uma oportunidade para sabermos quem somos, as razões pelas quais fazemos o que fazemos e consciencializar-nos do lugar que ocupamos na sociedade (Alarcão, 1996), através de uma experiência pedagógica inovadora e de uma nova perspetiva sobre o que é o currículo escolar. Definitivamente, o nosso posicionamento no que respeita ao ensino-aprendizagem de LE mudou. (Ferreira, 2014, p. 108)

De um modo mais concreto, é possível afirmar que ambas as intervenções educativas denotam que a IC pode inspirar práticas de inovação curricular no ensino/aprendizagem do ELE que contrariam as tendências descritas na investigação de compartimentalização e isolamento das línguas e das competências de linguagem, ou, por outras palavras, de culto de um "habitus monolingue" (Gogolin, 2008) inspirado numa conceção purista, estanque e formalizada da língua e na idealização e neutralização de um perfil de locutor. Esta doxa escolar tem freado consideravelmente a implementação das abordagens plurais em DL (Araújo e Sá, 2015), não obstante a estima generalizada de que elas parecem gozar (ver acima, Coste, 2010).

Indo mais longe, são inegáveis as aprendizagens realizadas pelos alunos nestas atividades de linguagem, indiciando o desenvolvimento da sua competência plurilingue e intercultural. Como afirmam Coste, Moore, e Zarate (2009), a escola é, seguramente, na sua relação com outros, um espaço privilegiado para a construção desta competência, que se entende aqui como própria de uma ética da comunicação humana (Morin, 2002), na medida em que traduz a capacidade e a vontade dos sujeitos de viverem não ao lado uns dos outros, mas uns com os outros, em sociedades onde cada um encontra o seu lugar e tem a sua voz. Ora a IC demonstrou ser um conceito didático que pode auxiliar o professor nesta tarefa, que se define, antes de tudo, como uma missão educativa. De referir ainda, nesta mesma linha, outras capacidades que os alunos mostram desenvolver, também evidenciadas por Alarcão (2015), quando sintetiza as potencialidades de inserção curricular da IC, a partir de uma análise de relatórios de experiências de terreno onde se incluem estas duas: "Besides learning languages and respecting cultures, the learners develop capabilities of working with others, using previous knowledge, interrelating knowledge, developing strategic competencies, using techonolgy, gaining self-confidence" (p. 7). 
Para concluir, e não obstante todos os limites e constrangimentos que os professores, nos seus relatórios, identificam nestas intervenções (ver Borges, 2014; Ferreira, 2014), é possível afirmar que nelas houve a possibilidade de criar e viver, com autonomia e criatividade, um conjunto didaticamente coerente de situações singulares de ensino/aprendizagem da língua, cujo contributo para o projeto de educação linguística da escola, traduzido, aqui, nas disciplinas de ELE, ficou evidenciado. Nesta medida, estudos como estes, que assentam nas dinâmicas de contextos específicos, ou nas "micropolíticas curriculares (Andrade, Pinho, \& Martins, 2011), podem ser inspiradores de outros, conduzidos em contextos escolares diversificados (outros professores e turmas, outras línguas, outros níveis de aprendizagem, outras escolas, outras regulações (supra)nacionais), que permitam à DL ir construindo, de forma sólida e fundamentada, os seus argumentos relativos à forma como os conceitos que a estruturam se vão transfigurando, ganhando novos e mais significativos matizes, nas mãos daqueles a quem verdadeiramente se dirigem: os educadores.

\section{Referências bibliográficas}

Alarcão, I. (2010). A constituição da área disciplinar de Didáctica das Línguas em Portugal. Lingvarvm Arena, 1(1), 61-79. Recuperado de https://bit.ly/2ZDsNNu

Alarcão, I. (2015). Prefácio. In M. H. Araújo e Sá \& A. S. Pinho (Orgs.), A Intercompreensão em contexto educativo: resultados da investigação (5-9). Aveiro: UA Editora.

Alarcão, I., Andrade, A.I., Araújo e Sá, M.H., Melo-Pfeifer, S., \& Santos, L. (2009). Intercompréhension et plurilinguisme : (re)configurateurs épistémologiques d'une didactique des langues? Etudes de Linguistique Appliquée, 153, 11-24.

Alarcão, I. \& Araújo E Sá, M. H. (2010). Era uma vez... a Didáctica de Línguas em Portugal. Aveiro: UA Editora. Recuperado de https://bit.ly/2ZEEXd6.

Andrade, A., Pinho, A.S., \& Martins, F. (2011). Formar para a intercompreensão: micro políticas curriculares. In A. S. Pinho \& A. I. Andrade (Orgs.), Intercompreensão e Didática de Línguas: histórias a partir de um projeto (57-79). Aveiro: UA Editora.

Andrade, A. I., Araújo e Sá, M. H., López Alonso, C., Melo, S., \& Séré, A. (2005). Plataforma Internet para o desenvolvimento da intercompreensão em línguas românicas. Manual do utilizador. Aveiro: Universidade de Aveiro.

Araújo e Sá, M. H. (2013). A Intercompreensão em Didática de Línguas: modulações em torno de uma abordagem internacional. Lingvarvm Arena, 4, 79-106. Recuperado de https://bit.ly/2NI7Pee.

Araújo e Sá, M. H. (Coord.) (2014). Atouts et possibilités de l'insertion curriculaire de I'intercompréhension: Rapport. MIRIADI. Recuperado de https://bit.Iy/2UfyRL8

Araújo e Sá, M. H. (Coord.) (2015). Histórias em Intercompreensão: a voz dos autores. Aveiro: UA Editora. Recuperado de https://bit.ly/2ztSaad 
Araújo e Sá, M. H. (2015). Investigadores e professores em intercompreensão: narrativas na primeira pessoa (do plural). In M. H. Araújo e Sá \& A. S. Pinho (Orgs.), A Intercompreensão em contexto educativo: resultados da investigação (37-75). Aveiro: UA Editora

Araújo e Sá, M. H., De Carlo, M., \& Melo-Pfeifer, S. (2010). ‘O que diriam sobre os portugueses?????': intercultural curiosity in multilingual chat-rooms. Language and Intercultural Communication, 10(4), 277-298.

Araújo e Sá, M. H., \& Espinha, Â. (2018). “Adios... che l'avventura cominci!:)": a construção da imagem de si enquanto motor da relação intercultural. Investigar em Educação, 2(7).

Araújo e Sá, M. H. \& Pinho, A.S. (Orgs.) (2015). A Intercompreensão em contexto educativo: resultados da investigação. Aveiro: UA Editora. Recuperado de https://bit.ly/32klyel

Araújo e Sá, M. H. \& Simões, A.R. (2015). Integração curricular da intercompreensão: possibilidades, constrangimentos, recomendações. Miriadi. Recuperado de https:// bit.ly/2MNS8SX

Beacco J. C., Cavalli, M., Coste, D., Egli-Cuenat, M., Goulier, F., \& Panthier, J. (2010). Guide pour le développement et la mise en oeuvre de curriculums pour une éducation plurilingue et interculturelle. Strasbourg: Conseil de l'Europe.

Blanchet, P. (2011). Nécéssité d'une réflexion épistémologique. In P. Blanchet \& P. Chardenet (Dir.), Guide pour la recherche en didactique des langues et des cultures (9-19). Paris: Editions des archives contemporaines.

Blanchet, P., \& Chardenet, P. (Dir.) (2011). Guide pour la recherche en didactique des langues et des cultures. Paris: Editions des archives contemporaines.

Borges, A.M. (2014). Integração curricular da Intercompreensão numa turma de Espanhol Língua Estrangeira (Dissertação de Mestrado não publicada). Universidade de Aveiro: Aveiro. Recuperado de https://bit.ly/2UihQzS

Capucho, F., Ollivier, O., \& Araújo e Sá, M. H. (no prelo). Les compétences en interaction plurilingue - trois dimensions saillantes. In Ch. Hülsmann, M. Strasser \& Ch. Ollivier, Lehr- und Lernkompetenzen für die Interkomprehension. Perspektiven für die mehrsprachige Bildung.

Conselho da Europa (2001). Quadro europeu comum de referência para as línguas. Porto: Edições Asa. Recuperado de https://bit.ly/2CmUylf

De Carlo, M. (Coord.) (2015). Deux référentiels de compétences en intercompréhension. Miriadi. Recuperado de https://bit.ly/30MomkS

Coste, D. (2010). L'intercompréhension à la croisée des chemins? Synergies Europe, 5, 193-199.

Coste, D., Moore, D. \& Zarate, G. (2009). Compétence plurilingue et pluriculturelle. Strasbourg: Editions du Conseil de l'Europe (edição original 1997).

Degache, C. (2018). Quels scénarios pour pratiquer l'intercompréhension interactive ? Entre double mise en abyme, vertige et effectif réduit, l'analyse itérative et contextualisée d'une session spécifique de formation. In S. Garbarino \& C. Degache (Orgs.), Intercompréhension en réseau Scénarios, médiations, évaluations(40-76). Lyon: CRT.

Egli Cuenat, M. (2009). Curricula pour une éducation plurilingue et interculturelle, formation des enseignants et profil européen. SemLang, 6, 1-15. 
Escudé, P. (2010). Origine et contexte d'apparition du terme d'intercompréhension dans sa première attestation (1913) chez le linguiste français Jules Ronjat (1864-1925). REDINTER-Intercompreensão, 1, 103-123.

Ferrão Tavares, C., \& Ollivier, C. (Coord.) (2010). O conceito de intercompreensão: origem, evolução e definições. Redinter-Intercompreensão, 1 .

Ferreira, F. (2014). Espanhol Língua Estrangeira em intercompreensão - integração curricular numa turma do percurso profissional (Dissertação de Mestrado não publicada). Universidade de Aveiro: Aveiro. Recuperado de https://bit.ly/2MHHPzX

Ginzburg, C. (1989). TRACES - Racines d'un paradigme indiciaire. In C. Ginzburg, Mythes, emblemes, traces: morphologie et histoire (139-180). Saint-Amand-Montrond: Flammarion.

Goetz, J.P., \& LeCompte, M.D. (1984). Ethnography and Qualitative Design in Educational Research. New York: Academic Press.

Gogolin, I. (2008). Der monolinguale Habitus der multilingualen Schule. Münster: Waxmann.

Miranda de Paulo, L. (2018). A intercompreensão no curso de Letras: formando sujeitos plurilingues a partir da leitura de textos académicos em línguas românicas (Tese de doutoramento não publicada). USP: São Paulo.

Morin, E. (2002). Os sete saberes para a educação do futuro. Lisboa: Instituto Piaget.

Ollivier, C., Capucho, F., \& Araújo e Sá, M.H. (no prelo). Defining IC competencies as prerequisites for their assessment. Rivista di Psicolinguistica Applicata, Special issue "The role of Intercomprehension in Language Learning".

Olmo, F., \& Cunha, K. (no prelo). C'era una volta a intercompreensão na UFPR: primeira década. In F. Olmo, K. Cunha, \& A. Shibayama (Orgs.), Práticas didáticas e pesquisas de ensino e aprendizagem de línguas e culturas estrangeiras (173-199). Curitiba: Editora UFPR.

Roldão, M.C. (2006). Currículo e Didácticas - percursos do conhecimento profissional. O Ensino da História, 32, 9-11.

Roldão, M.C. (2011). Um currículo de currículos. Chamusca: Edições Cosmos.

Sonsoles, F. (2001). Programa de espanhol nível de iniciação - $10^{\circ}$ Ano Formação Específica Cursos Científico-Humanísticos de Línguas e Literaturas, de Ciências Socioeconómicas e de Ciências Sociais e Humanas. Ministério da Educação, Departamento do Ensino Secundário.

Tadeu da Silva, T. (1999). Documentos de identidade. Uma introdução às teorias do currículo. Belo Horizonte: Autêntica.

Tadeu da Silva, T. (2006). Currículo como fetiche. A poética e a política do texto curricular. Horizonte: Autêntica. 